\title{
Nutritive value and metabolic effects of whey protein concentrate and hydrolysed lactose for growing pigs
}

\author{
MATTI NÄSI \\ Department of Animal Husbandry, University of Helsinki, \\ SF-00710 HELSINKI, Finland
}

\begin{abstract}
In two digestibility and balance trials with growing pigs, whey protein concentrate (WPC) was compared as a protein supplement with casein (CAS) and dried skim milk (DSM), and, $30 \%$ lactose (40 \% dried whey, DW) was compared as a sugar supplement with the same amounts of hydrolysed lactose (HYLA) and sucrose (SUC). The effects of these supplements on protein and mineral metabolism of the pigs were investigated. WPC contained $42.2 \%$ crude protein and had a high content of lysine, $8.6 \mathrm{~g}$, and sulphur containing amino acids: cystine 2.8 and methionine $2.2 \mathrm{~g} / 16 \mathrm{~g} \mathrm{~N}$. These exceeded the values for DSM. The hydrolysing degree of the enzymatically treated lactose syrup was $73 \%$. WPC had high crude protein digestibility, $99.1 \%$ as compared to 95.4 for CAS and $95.0 \%$ for DSM. Dried whey had low crude protein digestibility, $72.5 \%$. The amino acids in the WPC diet were highly digestible, but low values were obtained for the DW diet. On the WPC diet, nitrogen retention was higher than with the other protein supplements $(\mathrm{P}>0.05)$, urinary urea excretion was low and the biological value very high. On a combination of WPC and HYLA protein utilisation was higher than on dried whole whey. On the diets supplemented with different sugars, none of the blood parameters differed statistically significantly $(\mathrm{P}>0.05)$ and all values lay within the reference range. Water intake was on average $49 \%$ greater on diets with sugar supplements than without. Urinary excretion of reducing sugars averaged 40.2, 8.3 and 6.6 $\mathrm{g} / \mathrm{d}$ on the HYLA, SUC and DW diets, while on the diets without sugar supplements the values were $0.8-1.2 \mathrm{~g} / \mathrm{d}$. The following mean daily mineral retention values were obtained: P 4.0 g, Ca 5,9 g, Mg 0.4 g, Na 1.9 g, K 2.9 g, Fe 27 mg, Cu 6.4 mg, Zn 65 mg and Mn 4.0 $\mathrm{mg}$. The surplus $\mathrm{Na}$ and $\mathrm{K}$ on the DW diet were excreted in the urine and the pigs did not have diarrhoea.
\end{abstract}

\section{Introduction}

With the expansion of cheese manufacturing in Finland, increased amounts of whey are supplied for animal feeding, while minor amounts of whey products are used in the food industry. In 1983, the total production of whey was 650 mill. $\mathrm{kg}$, of which ca. $20 \%$ was used directly in liquid form by farm animals, the remainder being used to produce 26 mill. kg dried whey (ANON. 1983). Liquid whey contains a high proportion of 
water and only 5-7\% dry matter, which makes drying very expensive. Whey solids contain about $75 \%$ lactose, relatively little protein, $13 \%$, and $9 \%$ ash. Whey deteriorates rapidly and this, together with high transport costs, restricts its extensive use as a liquid feedstuff. Furthermore, large whey supplements, over $30-40 \%$ of energy intake, cause slow growth and digestional disturbances in growing pigs, due to the high lactose and mineral contents of whole whey (BARber et al. 1978, Fevrier 1978). Recent technological developments, such as enzymic hydrolysis of lactose, ultrafiltration and reverse osmosis, allow concentration of the protein and reduction of the lactose and mineral contents, thus eliminating the problems encountered when large amounts of whey are used in pig diets (HARJU 1984). Large amounts of hydrolysed lactose syrup and whey protein concentrate have been given to pigs with good results (AlaviUHKoLA et al. 1980, Alaviuhrola 1982, 1984).

The present physiological experiments were undertaken to assess the nutritive value and utility of some new whey products in pig diets and their effects on protein and mineral metabolism.

\section{Materials and methods}

Two digestibility, nitrogen and mineral balance experiments were conducted with three castrated Landrace pigs weighing $38-71 \mathrm{~kg}$ in trials of $3 \times 3$ Latin square design, to determine the nutritive value and metabolic effects of some whey products of the new process technology. In one experiment ultrafiltrated spray-dried whey protein concentrate (WPC) was compared as a protein supplement with hydrochloric acid-precipitated spray-dried casein (CAS) and spraydried skim milk (DSM). In the other experiment, spray-dried whole whey (DW) was compared as a lactose supplement with sucrose (SUC) and Hydrolact L-50 enzyme hydrolyzed lactose syrup (HYLA), hydrolyzing min. $73 \%$. The experimental substances were normal products of the firm Kuivamaito Oy, Lapinlahti. Six isonitrogenous diets were prepared, using barley meal enriched with mineral mixture (Seleeni-Terki, $40 \mathrm{~g} / \mathrm{d}$ ) and vitamin mixture (Vitamiini-Nasu, 15 $\mathrm{g} / \mathrm{d})$, the percentages of supplements the in the diets being as follows:

The daily rations were $1.8,2.2$ and $2.6 \mathrm{~kg}$, on average $97.3 \mathrm{~g} \mathrm{DM} / \mathrm{kg} \mathrm{W}^{0.75}$. The barrows were kept in metabolism cages, which allowed separate quantitative collection of urine and faeces. They were fed a slurry of $1 \mathrm{~kg}$ diet and 1.5 litre water twice daily. Each experiment lasted 16 days, consisting of a 4-day transition period, a 6-day accommondation period and a 6-day collection period.

Blood samples were taken from the anterior vena cava after each collection period before morning feeding. The treatment of samples and the methods used were the same as described by NÄsI and TANHUANPĀĀ (1981). The chemical analyses of feeds and faeces were performed according to the official procedures. Amino acids were deter-

\begin{tabular}{|c|c|c|c|c|c|c|}
\hline & \multicolumn{3}{|c|}{ Protein supplements } & \multicolumn{3}{|c|}{ Sugar supplements } \\
\hline & WPC & CAS & DSM & HYLA & SUC & DW \\
\hline Barley & 88 & 94.5 & 85 & 45 & 45 & 49 \\
\hline Whey protein conc. & 12 & - & - & 25 & 25 & 11 \\
\hline Casein & - & 5.5 & - & - & - & - \\
\hline Skim milk powder & - & - & 15 & - & - & - \\
\hline Dried whey & - & - & - & - & - & 40 \\
\hline Hydrol. lactose syrup & - & - & - & 30 & - & - \\
\hline Sucrose & - & - & - & - & 30 & - \\
\hline
\end{tabular}


mined on the diet ingredients and faeces with a Technicon TSM autoanalyzer. Minerals were measured with a Varian Techtron AA1000 atomabsorption spectrophotometer. Phosphorus was determined by the method of TAYSSKY and SHORR (1953), sodium and potassium concentrations were determined by flame photometer (Corning 435). The osmolality of the urine was analysed by the freezing point depression method with a Fiske osmometer.

\section{Results and discussion}

The chemical composition of the experimental feeds is shown in Table 1. The whey protein concentrate had a proximal composition comparable to that of dried skim milk. Whey protein is mostly composed of $\beta$-lactoglobulin and $\alpha$-lactalbumin, thus differing in its amino acid profile from casein and skim milk, in which casein constitutes approximately $80 \%$ of total protein (Fox 1982). Whey

Table 1. Chemical composition of the experimental feeds.

\begin{tabular}{|c|c|c|c|c|c|c|}
\hline In dry matter & Barley & $\begin{array}{l}\text { Dried } \\
\text { skim } \\
\text { milk }\end{array}$ & Casein & $\begin{array}{l}\text { Dried } \\
\text { whey }\end{array}$ & $\begin{array}{l}\text { Whey } \\
\text { prot. } \\
\text { conc. }\end{array}$ & $\begin{array}{c}\text { Hydrol. } \\
\text { lactose } \\
\text { syrup }\end{array}$ \\
\hline Dry matter, \% & 88.0 & 95.6 & 88.6 & 94.1 & 95.5 & 56.6 \\
\hline Ash, $\%$ & 2.8 & 8.4 & 3.3 & 10.4 & 6.0 & 2.3 \\
\hline Crude protein, $\%$ & 10.9 & 38.3 & 89.5 & 16.8 & 42.2 & 0.3 \\
\hline True protein, $\%$ & 9.3 & 35.1 & 86.4 & 13.6 & 39.3 & 0.1 \\
\hline Ether extract, $\%$ & 2.4 & 0.7 & 1.1 & 1.5 & 4.7 & 0.3 \\
\hline Crude fibre, $\%$ & 7.4 & - & - & - & - & - \\
\hline NFE, $\%$ & 76.6 & 52.6 & 6.1 & 71.3 & 47.1 & 97.1 \\
\hline \multicolumn{7}{|l|}{ Amino acids, $\mathrm{g} / 16 \mathrm{~g} \mathrm{~N}$} \\
\hline Alanine & 3.5 & 2.7 & 2.7 & 3.7 & 4.5 & \\
\hline Arginine & 4.6 & 3.3 & 3.5 & 2.0 & 2.5 & \\
\hline Aspartic acid & 6.6 & 8.7 & 7.9 & 11.3 & 11.9 & \\
\hline Cystine & 3.5 & 1.2 & 0.7 & 2.8 & 2.8 & \\
\hline Glutamic acid & 19.0 & 19.4 & 21.3 & 15.1 & 17.8 & \\
\hline Glycine & 3.8 & 1.8 & 1.8 & 1.8 & 2.2 & \\
\hline Histidine & 2.3 & 2.6 & 2.9 & 1.8 & 2.2 & \\
\hline Isoleucine & 2.6 & 4.3 & 4.3 & 4.2 & 5.0 & \\
\hline Leucine & 6.1 & 8.9 & 9.0 & 8.5 & 10.2 & \\
\hline Lysine & 3.4 & 7.4 & 7.4 & 4.8 & 8.6 & \\
\hline Methionine & 1.1 & 2.6 & 2.9 & 1.7 & 2.2 & \\
\hline Phenylalanine & 4.1 & 4.3 & 4.9 & 2.6 & 3.3 & \\
\hline Serine & 3.9 & 5.1 & 5.6 & 4.4 & 5.1 & \\
\hline Threonine & 3.9 & 4.0 & 4.2 & 6.2 & 6.7 & \\
\hline Tyrosine & 2.1 & 4.4 & 5.2 & 2.0 & 2.8 & \\
\hline Valine & 4.6 & 5.2 & 5.6 & 4.9 & 5.1 & \\
\hline \multicolumn{7}{|l|}{ Minerals } \\
\hline Phosphorus, g/kg DM & 3.98 & 9.33 & 8.45 & 7.60 & 6.16 & 4.14 \\
\hline Calcium, g/ kg DM & 0.53 & 9.32 & 3.60 & 7.05 & 6.33 & 0.30 \\
\hline Magnesium, g/kg DM & 1.14 & 1.05 & 0.25 & 1.52 & 1.01 & 0.10 \\
\hline Sodium, g/kg DM & 0.59 & 6.02 & 0.59 & 9.05 & 4.16 & 0.65 \\
\hline Potassium, g/ kg DM & 6.05 & 17.05 & 2.19 & 28.78 & 13.30 & 9.47 \\
\hline Iron, $\mathrm{mg} / \mathrm{kg} \mathrm{DM}$ & 64 & 8 & 3 & 12 & 6 & 8 \\
\hline Copper, mg/kg DM & 9 & 6 & 0 & 6 & 3 & 6 \\
\hline Zinc, $\mathrm{mg} / \mathrm{kg}$ DM & 61 & 44 & 57 & 3 & 5 & 0 \\
\hline Manganese, mg/kg DM & 21 & 0 & 0 & 3 & 0 & 0 \\
\hline
\end{tabular}


proteins are rich in lysine and sulphur-containing amino acids; the cystine level in WPC greatly exceeded the concentrations in CAS and DSM (Table 1). The high levels of lysine and threonine in WPC make it specially valuable as a protein source for pigs receiving grain supplements, which are low in these amino acids. WPC had lower amounts of arginine, phenylalanine and tyrosine than CAS or DSM. The dried whey used in the present study had an unusually low lysine content, $4.8 \mathrm{~g} / 16 \mathrm{~g} \mathrm{~N}$, as opposed to the value of 6.8 $\mathrm{g} / 16 \mathrm{~g} \mathrm{~N}$ reported by SALO et al. (1982). During drying lactose and lysine can react, causing browning and reducing the contents of lysine and other amino acids (ERBERSDOBLER 1983). Milk products are rich in minerals and DW had high contents of potassium and sodium. Hyla had a low value for sodium and also a greatly reduced potassium content. High potassium and sodium contents impose limits on the amount of whey which can be fed to pigs. The reverse osmosis technique makes it possible to reduce the mineral contents and obtain partially demineralized whey products (HARJU 1984).

The diet supplemented with casein had lower organic matter digestibility $(\mathrm{P}<0.05)$ than the diets with other protein supplements. The diet including dried whey had lower dry matter, organic matter and NFE digestibilities than the diets supplemented with other sugars $(\mathrm{P}<0.05, \mathrm{P}<0.01)$ (Table 2). The crude protein digestibility of the DW diet was $9 \%$ units and $5 \%$ units lower than the values for the SUC and HYLA diets, but the differences were not statistically significant $(\mathrm{P}>0.05)$. Forsum (1975) reported decreased true protein digestibilities when dietary lactose increased. However, EGGUM (1973) reported that lactose does not affect the digestibility of proteins. On the WPC, CAS and DSM diets reducing sugars were excreted in urine of the pigs at the rates of $1.1,0.8$ and $1.2 \mathrm{~g} / \mathrm{d}$, respectively, and on the HYLA, SUC and DW diets at the rates of $40.2,8.3$ and $6.6 \mathrm{~g} / \mathrm{d}$. The excretion on the HYLA diet was remarkably high compa- red with that on the diets with other sugar supplements. The water intakes were increased on the diets supplemented with sugars; on the WPC, CAS, DSM, HYLA, SUC and DW diets they averaged, respectively: 4.35 , $4.38,4.68,6.81,5.80$ and $7.43 \mathrm{~kg} / \mathrm{d}$.

The overall amino acid digestibilities were higher on the WPC diet than on the CAS or DSM diets, the CAS diet giving the lowest values. This diet had significantly $(\mathrm{P}<0.05, \mathrm{P}<0.01)$ lower digestibilities than the WPC diet, but not the DSM diet, for aspartic acid, isoleucine, leucine, lysine and threonine. The diet including DW had lower digestibilities for the most essential amino acids than the diets supplemented with other sugars $(\mathrm{P}>0.05, \mathrm{P}<0.01)$. On the DW diet, it is possible that not all the lactose can be absorbed in the small intestine and that part is fermented in the large intestine, thus lowering the apparent amino acid digestibilities. But the low lysine content of DW indicates thermal denaturation of protein during drying and reduced digestibility and availability. The pigs on the DW diet had slightly loose and foamy excrements, but no diarrhoea was observed and the DM content of the faeces on the various diets was $29.2,29.5,31.3,31.8,31.8$ and $29.7 \%$.

The digestibility of crude protein in WPC, calculated by the difference method, was $99.1 \%$, compared to 95.4 for CAS and $95.0 \%$ for DSM (Table 3). Dried whey had rather low CP digestibility, 72.5\% compared, to the other milk proteins. JUST et al. (1983) also received a low value, $78 \%$, for the crude protein digestibility of DW, while SALo et al. (1982) reported the higher value of $90 \%$. However, the digestibility of the organic matter of dried whey in the present study was similar to that reported by HANRAHAN (1971) and Just et al. (1983). The whey protein concentrate had a FU value $10.5 \%$ higher than that of dried skim milk, and hydrolysed lactose syrup also had a high value, only $3.5 \%$ lower than sucrose. The high feed values of WPC and HYLA ob- 


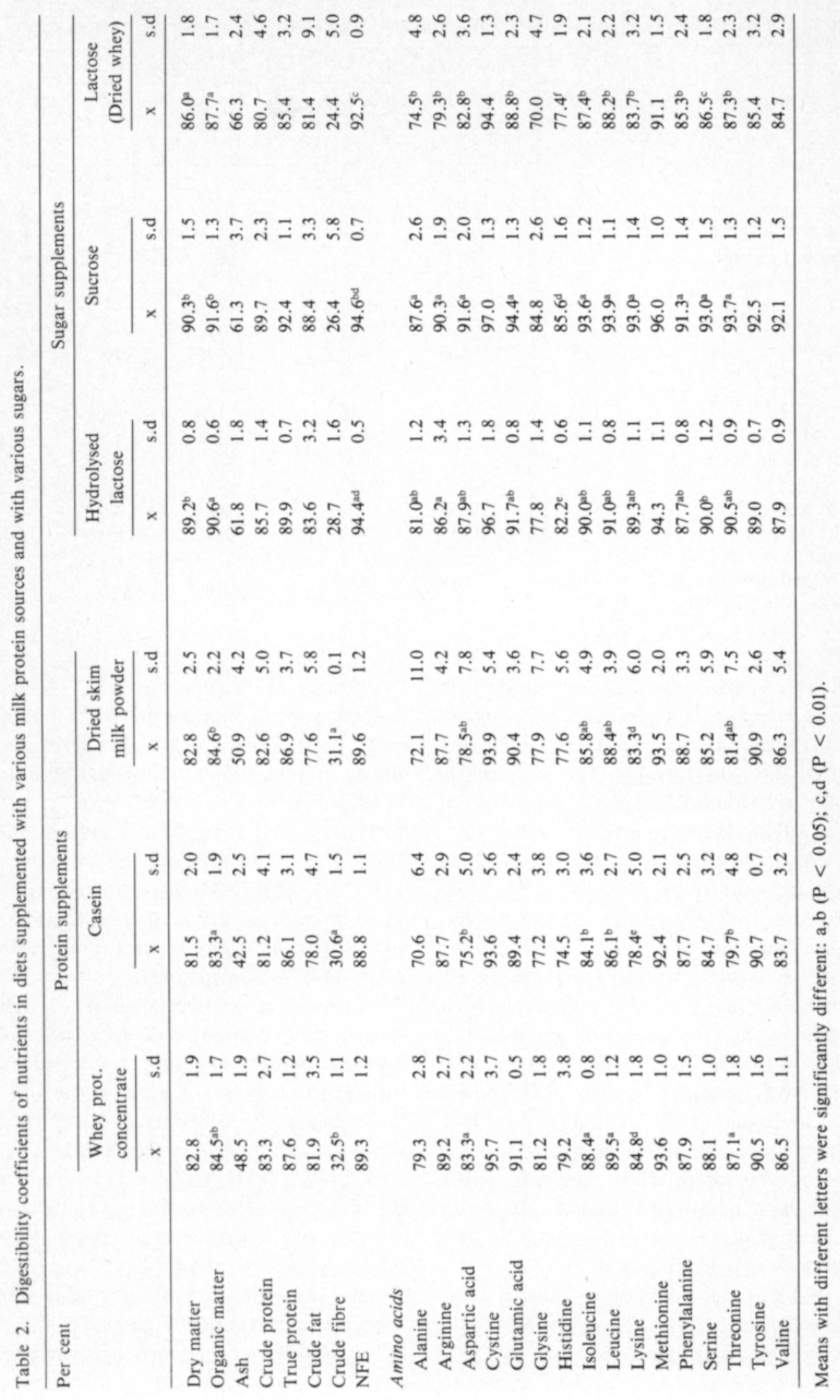


Table 3. Digestibility coefficients of experimental feeds calculated by the difference and their feed values.

\begin{tabular}{|c|c|c|c|c|c|c|}
\hline & \multicolumn{3}{|c|}{ Protein supplements } & \multicolumn{3}{|c|}{ Sugar supplements } \\
\hline & $\begin{array}{c}\text { Whey } \\
\text { protein } \\
\text { concentr. }\end{array}$ & Casein & $\begin{array}{l}\text { Dried } \\
\text { skim } \\
\text { milk }\end{array}$ & $\begin{array}{c}\text { Hydrol. } \\
\text { lactose }\end{array}$ & Sucrose & $\begin{array}{c}\text { Lactose } \\
\text { (Dried } \\
\text { whey) }\end{array}$ \\
\hline \multicolumn{7}{|l|}{ Degestibility } \\
\hline Dry matter & 96.7 & 93.1 & 94.0 & 96.0 & 99.2 & 89.8 \\
\hline Ash & 99.9 & 99.9 & 99.6 & 72.1 & - & 80.6 \\
\hline Organic matter & 97.2 & 93.4 & 95.0 & 96.4 & 98.9 & 91.1 \\
\hline Crude protein & 99.1 & 95.4 & 95.0 & - & - & 72.5 \\
\hline True protein & 98.1 & 95.5 & 95.0 & - & - & 78.5 \\
\hline Crude fat & 98.8 & 99.9 & 90.0 & - & - & 74.4 \\
\hline NFE & 93.7 & 68.9 & 95.0 & 99.9 & 99.9 & 96.8 \\
\hline \multicolumn{7}{|l|}{ Feed values } \\
\hline FU/kg DM & 1.36 & 1.26 & 1.23 & 1.38 & 1.43 & 1.19 \\
\hline $\mathrm{kg} / \mathrm{FU}$ & 0.77 & 0.90 & 0.85 & 1.28 & 0.70 & 0.89 \\
\hline DCP $\%$ in DM & 41.8 & 85.4 & 36.4 & - & - & 12.1 \\
\hline DCP $\mathrm{g} / \mathrm{FU}$ & 307 & 680 & 296 & - & - & 102 \\
\hline $\mathrm{ME} \mathrm{MJ/kg} \mathrm{DM} \mathrm{(Just)}$ & 18.28 & 19.37 & 16.56 & 16.67 & 17.17 & 14.89 \\
\hline NE MJ/kg DM (Just) & 11.83 & 12.65 & 10.54 & 10.62 & 11.00 & 9.29 \\
\hline NE FU/kg DM (Just) & 1.53 & 1.64 & 1.37 & 1.38 & 1.43 & 1.20 \\
\hline ME MJ/kg DM (Axels.) & 17.44 & 17.59 & 15.80 & 16.66 & 17.17 & 14.64 \\
\hline
\end{tabular}

tained here are in good agreement with the results of pig growth trials in which soybean - fish meal was replaced with WPC, which improved the daily gain by $9 \%$ and also the feed conversion efficiency by $9 \%$ (AlaviuHKOLA 1982). Replacement of barley with HYLA at the levels of 30 and $45 \%$ of the feed units improved daily gains by 8 and $4 \%$, while DW inclusion gave a $3 \%$ increase (Alaviuhrola et al. 1980). Good performances were also obtained in pig feeding experiments, when WPC was used as a protein supplement and the ration contained $28.5 \%$ and $52.4 \%$ HYLA, but pigs receiving over $70 \%$ whey products in their diets showed $6 \%$ lower daily gain (AlaviuhKola 1984). With diets containing $60 \%$ hydrolysed lactose or untreated whey, Fevrier (1980) found that hydrolysed lactose raised the energy and protein digestibilities from 85.4 to $87.5 \%$ and from 74.8 to $80.6 \%$.

Table 4 presents data on the nitrogen balance with the different diets. The WPC diet had the highest nitrogen retention, $25.5 \mathrm{~g} / \mathrm{d}$, which exceeded the value for the CAS diet by
$7.9 \%$ and for the DSM diet by $2.7 \%$. A wet carboxy methyl cellulose precipitated (CMC) whey product gave still higher retention of nitrogen and a higher biological value (NÄsı et al. 1982) than the WPC product in the present study. Urinary urea excretion on the WPC diet was $14 \%$ and $18 \%$ lower than on the CAS and DSM diets, indicating very good amino acid availability and balance in the WPC diet. The biological value was also high, $73.4 \%$. Consequently, ultrafiltration of whey gives a protein source which is largerly undenaturalized (Forsum 1975). The DW diet had the lowest values for nitrogen utilization. This was in accordance with the daily gains, which averaged $910 \mathrm{~g}$ for the other diets and $750 \mathrm{~g}$ for the DW diet. However, EgGum (1973) found that in most cases the biological value was improved by lactose supplements. THORBEK et al. (1961) also obtained an higher protein deposition in 3065 -days-old piglets fed casein + lactose than in animals given casein + glucose or sucrose. Whey powder is produced by evaporation and drying at comparatively high tempera- 
tures, and lactose is a reducing sugar, which can react with lysine, with a consequent Maillard reaction and other denaturation effects on the amino acids.

Whey proteins are among the highestquality natural proteins available; in experiments with rats the protein efficiency ratio (PER) of whey protein was approximately $20 \%$ greater than the PER of casein (DEMOTT 1972, FoRSUM 1974, 1975), $10 \%$ greater than the PER of skim milk on wheat diets (WOMACK and VAgHAN 1972). The balance data of the present investigation accord with the improved performance of pigs fed WPC instead of soybean - fish meal protein with an equivalent amino acid supply (ALAviUHKOLA 1982). They also agree with the metabolic performances of piglets on diets with casein to whey protein ratios ranging from $80: 20$ to $0: 100$; in that study the CAS : WPS ratio of $40: 60$ gave the highest rate of gain, the urea $\mathrm{N}$ in total urinary $\mathrm{N}$ was inversely related to the proportion of whey protein in the diet, and the plasma urea was low throughout (HensCHEL et al. 1983).

The pigs on the WPC diet had a significantly $(\mathrm{P}<0.05)$ higher potassium content in the blood than the pigs on the other diets (Table 5). The alkaline phosphatase of the pigs on the WPS diet was lower than in the pigs on the DSM diet $(\mathrm{P}<0.05)$. In the pigs on the diets supplemented with different sugars, none of the blood parameters showed statistically significant differences ( $P>0.05)$. Blood glucose was similar to that in the pigs not receiving sugar supplements. Rerat et al. (1984) found that a lactose supplement of $400-1600 \mathrm{~g} / \mathrm{d}$ in the diet, as opposed to sucrose or glucose, resulted in only a small and constant amount of reducing sugars in the portal blood and that after the meal the sugar level remained above the initial value longer than with the other sugars. Although the pigs on the DW diet had high intakes of sodium and potassium, their blood values did not differ from those of the other pigs. The blood values in

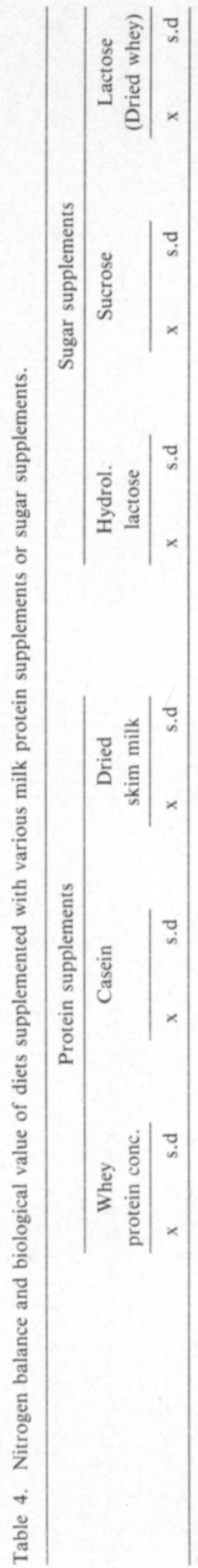

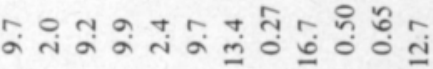
ๆ

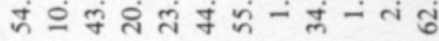

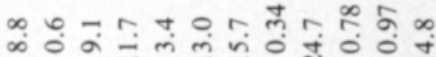

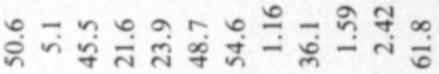

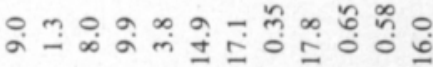


m

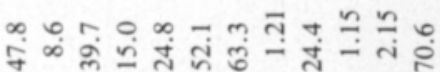

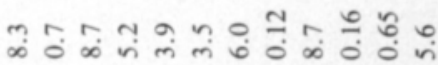

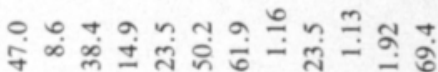
붕 4

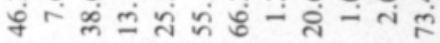

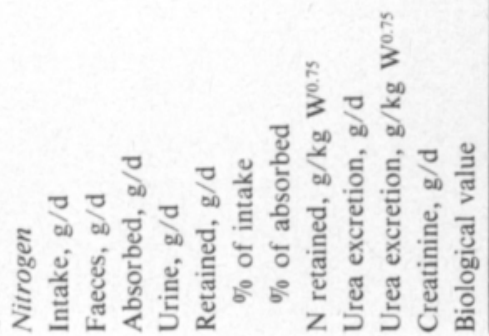




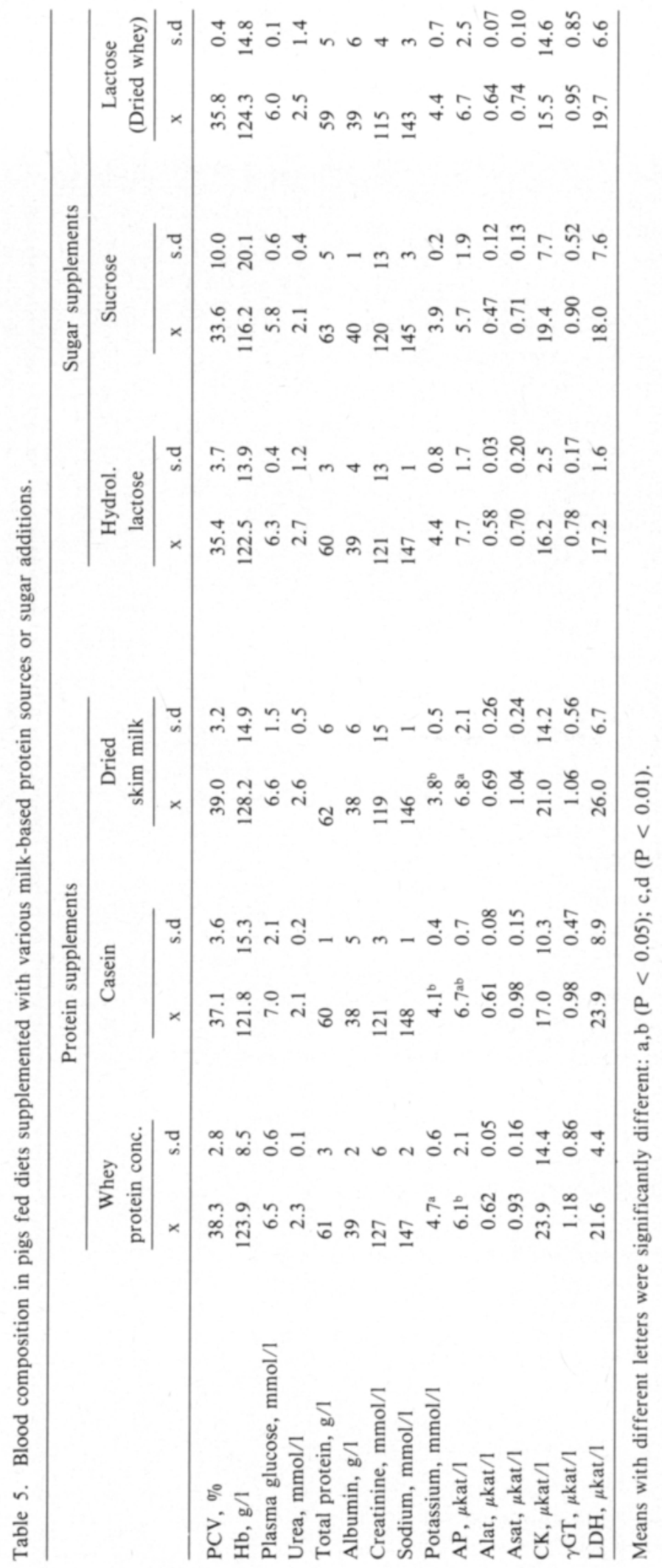


the present study correspond fairly closely to the results obtained in other experiments in which the diets were supplemented with sugar alcohols or whey protein product (NÄSI and TANHUANPÃÃ 1981, NÄSI et al. 1982), and all parameters lie within the reference ranges (SCHMIDT 1979).

The mineral metabolism was studied by measuring intake, and faecal and urinary excretion, and using the results to calculate absorption and retention (Table 6). The pigs received the same mineral supplements and the differences in the intakes were due to differences the mineral composition of the diets. The absorption of $\mathrm{P}$ and $\mathrm{Ca}$ averaged $50-51 \%$, that of $\mathrm{Mg}$ was very low, $25 \%$, and the values for $\mathrm{Na}$ and $\mathrm{K}$ were high, $89-79 \%$. The overall digestibilities of the trace elements were low, $8-37 \%$. Urinary excretion of $\mathrm{P}, \mathrm{Ca}$ and $\mathrm{Mg}$ and also that of trace elements was low, while surplus $\mathrm{Na}$ and $\mathrm{K}$ were voided in the urine. Water intake was about $40 \%$ higher in the pigs on the DW diet than in the pigs on the CAS diet, on the latter diet the pigs received $3.7 \mathrm{~g} \mathrm{Na} / \mathrm{d}$ and $11.3 \mathrm{~g} \mathrm{~K}$, compared to 11.6 and $32.8 \mathrm{~g} / \mathrm{d}$, respectively, on the DW diet. Urinary osmolalities on the different diets were 529, 515,
493, 337, 484 and $463 \mathrm{mosm} / \mathrm{kg}$ urine and were not higher in the pigs voiding surplus $K$ and $\mathrm{Na}$. The urine excretion was higher on the diets with high mineral supplies, averaging 2.31, 2.36, 2.82, 5.52, 4.17 and $5.58 \mathrm{~kg} / \mathrm{d}$ on the WPC, CAS, DSM, HYLA, SUC and DW diets, respectively. High intakes of $\mathrm{K}$ and $\mathrm{Na}$ did not lead to diarrhoea.

The following average daily retention values were obtained for the pigs on the various diets: $\mathrm{P} 4.0 \pm 0.7 \mathrm{~g}, \mathrm{Ca} 5.9 \pm 1.2 \mathrm{~g}, \mathrm{Mg}$ $0.4 \pm 0.1 \mathrm{~g}, \mathrm{Na} 1.9 \pm 0.4 \mathrm{~g}, \mathrm{~K} 2.9 \pm 0.8 \mathrm{~g}, \mathrm{Fe}$ $27 \pm 14 \mathrm{mg}, \mathrm{Cu} 6.4 \pm 2.1 \mathrm{mg}, \mathrm{Zn} 65 \pm 24 \mathrm{mg}$, $\mathrm{Mn} 4.0 \pm 2.9 \mathrm{mg}$. The retention of $\mathrm{P}, \mathrm{Ca}$ and $\mathrm{Mg}$ was a little higher on the diets including lactose, but the differences were not significant $(\mathrm{P}>0.05)$. $\mathrm{Na}$ and $\mathrm{K}$ retention was almost independent of the level in the diet. Lactose in the diet generally stimulates the mineral absorption and the minerals in milk products are readily available (SCHINGOETHE 1976). The rates of absorption and retention obtained for the various minerals obtained in the present study are in good agreement with the results presented recently by JøRGENSEN and Fernandez (1984).

Acknowledgements. Thanks are due to Miss Irma Klemetti for technical assistance.

\section{References}

Alaviuhrola, T. 1982. Heravalkuainen sopii sianlihantuotantoon. Karjatalous 58 (12): 35-36.

- 1984. Användning av vassleproducter till slaktsvin. Fodrets koncentrationsgrad till svin ur foder- och avelssynpunkt. NJF Seminarium Nr 57 12: 1-6.

-, Harju, M., Heikonen, M. \& Kreula, M. 1980. The effect of the hydrolysis of lactose in whey on its value in the feeding of growing-finishing pigs. Acta Agric. Scand. 30: 13-16.

ANoN. 1983. Suomen osuusmeijerien liiketilasto LXXX. Helsinki 75 p.

Barber, R.S., Braude, R., Michell, K.G. \& Pittman, R.J. 1978. The nutritive value of liquid whey, either sour or sweet, when given in restricted amounts to the growing pig. Anim. Feed Sci. Technol. 3: 163-177.
Demotт, B.J. 1972. Nutritional value of casein and whey protein. Food Prod. Dev. 6: 88.

Erbersdobler, H.F. 1983. Protein utilization and amino acid availability in milk products after treatment. Kieler Milchwirtsch. Forschungsber. 35: (3) 301-311.

Egcum, B.O. 1973. A study of certain factors influencing protein utilization in rats and pigs. Beretn. 406. National Institute of Animal Science.

Fevrier, C. 1978. Use of dried whey in pig diets. I Interaction with the dietary protein level according to growth stage and sex. Ann. Zootech. 27: 195-210.

-1980 . Growth and body characteristics of $20-100$ $\mathrm{kg}$ pigs as affected by the intake of large untreated or hydrolysed whey concentrate. Ann. Nutr. Aliment. 34: $22-23$. 
Table 6. Mineral balance in pigs fed diets supplemented with various milk based protein sources of sugar additions.

\begin{tabular}{|c|c|c|c|c|c|c|c|c|}
\hline & \multicolumn{3}{|c|}{ Protein supplements } & \multicolumn{3}{|c|}{ Sugar supplements } & \multicolumn{2}{|c|}{ Overall } \\
\hline & WPC & CAS & DSM & HYLA & SUC & DW & mean & s.d. \\
\hline \multicolumn{9}{|l|}{ Phosphorus } \\
\hline Intake, $\mathrm{g} / \mathrm{d}$ & $9.9^{b}$ & $9.8^{b}$ & $11.1^{\mathrm{a}}$ & $11.0^{f}$ & 8.48 & $13.2^{\mathrm{e}}$ & 10.6 & 1.9 \\
\hline Faeces, g/d & 5.1 & 4.9 & 5.7 & $5.0^{f g}$ & $3.8^{8}$ & $7.3^{e}$ & 5.3 & 1.8 \\
\hline Absorbed, g/d & 4.8 & 4.9 & 5.4 & 6.0 & 4.6 & 6.0 & 5.3 & 1.1 \\
\hline Urine, $\mathrm{g} / \mathrm{d}$ & 1.1 & 1.6 & 1.6 & 1.6 & 0.5 & 1.4 & 1.3 & 0.7 \\
\hline Retained, g/d & 3.8 & 3.3 & 3.9 & 4.5 & 4.1 & 4.6 & 4.0 & 0.7 \\
\hline$\%$ of intake & 38 & 34 & 34 & 41 & 49 & 35 & 38 & 6 \\
\hline$\%$ of absorded & 88 & 68 & 72 & $75^{\mathrm{bc}}$ & $91^{a}$ & $78^{\mathrm{ac}}$ & 77 & 9 \\
\hline $\mathrm{mg} / \mathrm{kg} \mathrm{W}^{0.75}$ & 184 & 166 & 187 & 207 & 197 & 217 & 193 & 27 \\
\hline \multicolumn{9}{|l|}{ Calcium } \\
\hline Intake, $\mathrm{g} / \mathrm{d}$ & $10.8^{\text {bef }}$ & $9.7 \mathrm{cf}$ & $12.2^{\mathrm{ae}}$ & $12.4^{b}$ & $12.2^{\mathrm{b}}$ & $16.2^{\mathrm{a}}$ & 12.3 & 2.2 \\
\hline Faeces, g/d & 5.2 & 4.6 & 6.0 & $5.7^{\mathrm{b}}$ & $5.0^{b}$ & $9.1^{\mathrm{a}}$ & 5.9 & 1.6 \\
\hline Absorded, g/d & 5.6 & 5.1 & 6.2 & 6.7 & 7.2 & 7.1 & 6.3 & 1.3 \\
\hline Urine, $\mathrm{g} / \mathrm{d}$ & 0.2 & 0.2 & 0.2 & 0.4 & 0.7 & 0.8 & 0.4 & 0.3 \\
\hline Retained, g/d & 5.4 & 4.9 & 6.0 & 6.3 & 6.6 & 6.2 & 5.9 & 1.2 \\
\hline$\%$ of intake & 50 & 50 & 49 & 51 & 54 & 38 & 49 & 8 \\
\hline$\%$ of absorded & 96 & 96 & 96 & $94^{a}$ & $91^{\mathrm{ac}}$ & $88^{\mathrm{bc}}$ & 93 & 4 \\
\hline $\mathrm{mg} / \mathrm{kg} \mathrm{W}^{0.75}$ & 264 & 244 & 287 & 290 & 309 & 291 & 281 & 30 \\
\hline \multicolumn{9}{|l|}{ Magnesium } \\
\hline Intake, $\mathrm{g} / \mathrm{d}$ & $3.3^{f}$ & $3.3 \mathrm{~s}$ & $3.4^{e}$ & $2.8^{\mathrm{b}}$ & $2.7^{b}$ & $3.8^{\mathrm{a}}$ & 3.2 & 0.5 \\
\hline Faeces, g/d & 2.6 & 2.6 & 2.7 & 1.9 & 2.0 & 2.7 & 2.4 & 0.4 \\
\hline Absorbed, g/d & 0.8 & 0.7 & 0.6 & 0.8 & 0.8 & 1.1 & 0.8 & 0.2 \\
\hline Urine, $\mathrm{g} / \mathrm{d}$ & 0.4 & 0.4 & 0.4 & $0.5^{\mathrm{a}}$ & $0.4^{b}$ & $0.6^{a}$ & 0.4 & 0.2 \\
\hline Retained, g/d & 0.4 & 0.3 & 0.3 & 0.4 & 0.4 & 0.5 & 0.4 & 0.1 \\
\hline$\%$ of intake & 12 & 9 & 8 & 13 & 13 & 12 & 11 & 4 \\
\hline$\%$ of absorded & 52 & 44 & 45 & 45 & 44 & 43 & 46 & 12 \\
\hline $\mathrm{mg} / \mathrm{kg} \mathrm{W} \mathrm{W}^{0.75}$ & 20.1 & 14.6 & 13.9 & 16.4 & 16.3 & 22.5 & 17.2 & 6.7 \\
\hline \multicolumn{9}{|l|}{ Sodium } \\
\hline Intake, $\mathrm{g} / \mathrm{d}$ & $4.6^{\text {bef }}$ & $3.7 \mathrm{ef}$ & $5.5^{\mathrm{ac}}$ & $5.7^{\mathrm{bc}}$ & $5.3^{\mathrm{c}}$ & $11.6^{a}$ & 6.1 & 2.7 \\
\hline Faeces, g/d & 0.9 & 0.8 & 1.0 & 0.4 & 0.5 & 0.5 & 0.7 & 0.3 \\
\hline Absorbed, g/d & $3.7^{\mathrm{b}}$ & $2.9^{\mathrm{c}}$ & $4.4^{a}$ & $5.3^{\mathrm{bc}}$ & $4.8^{c}$ & $11.1^{\mathrm{a}}$ & 5.4 & 2.8 \\
\hline Urine, $\mathrm{g} / \mathrm{d}$ & 1.8 & 1.0 & 2.5 & $3.4^{b c}$ & $3.2^{c}$ & $8.8^{\mathrm{a}}$ & 3.5 & 2.6 \\
\hline Retained, g/d & 1.9 & 1.9 & 1.9 & 1.9 & 1.6 & 2.4 & 1.9 & 0.4 \\
\hline$\%$ of intake & 42 & 51 & 35 & $33^{\mathrm{a}}$ & $30^{a}$ & $20^{b}$ & 35 & 10 \\
\hline$\%$ of absorded & 52 & 66 & 43 & 43 & 33 & 21 & 43 & 16 \\
\hline $\mathrm{mg} / \mathrm{kg} \mathrm{W}^{0.75}$ & 93.7 & 93.9 & 93.9 & 87.3 & 75.7 & 111.5 & 92.7 & 12.7 \\
\hline \multicolumn{9}{|l|}{ Potassium } \\
\hline Intake, $\mathrm{g} / \mathrm{d}$ & $13.7^{\text {bef }}$ & $11.3^{\mathrm{gf}}$ & $15.4^{\text {ae }}$ & $18.3^{b}$ & $12.4^{b}$ & $32.8^{\mathrm{a}}$ & 17.3 & 7.9 \\
\hline Faeces, g/d & 3.9 & 4.8 & 3.8 & $3.3^{\mathrm{a}}$ & $2.2^{\mathrm{b}}$ & $3.6^{\mathrm{a}}$ & 3.6 & 1.2 \\
\hline Absorbed, g/d & $9.7^{\mathrm{ac}}$ & $6.5^{\mathrm{bc}}$ & $11.6^{\mathrm{a}}$ & $15.0^{\mathrm{b}}$ & $10.2^{b}$ & $29.2^{\mathrm{a}}$ & 13.7 & 7.9 \\
\hline Urine, $\mathrm{g} / \mathrm{d}$ & $6.4^{a}$ & $3.4^{b}$ & $9.0^{\mathrm{a}}$ & $12.6^{r}$ & $8.0^{f}$ & $25.6^{\mathrm{e}}$ & 10.8 & 7.6 \\
\hline Retained, g/d & 3.3 & 3.1 & 2.6 & 2.4 & 2.3 & 3.6 & 2.9 & 0.8 \\
\hline$\%$ of intake & 24 & 27 & 17 & 13 & 19 & 11 & 19 & 7 \\
\hline$\%$ of absorded & 34 & 47 & 23 & 16 & 23 & 12 & 26 & 13 \\
\hline $\mathrm{mg} / \mathrm{kg} \mathrm{W}^{0.75}$ & 159 & 150 & 127 & 114 & 111 & 170 & 139 & 33 \\
\hline \multicolumn{9}{|l|}{ Iron } \\
\hline Intake, $\mathrm{mg} / \mathrm{d}$ & $240^{\mathrm{b}}$ & $247^{a}$ & $240^{\mathrm{b}}$ & $196^{b}$ & $192^{b}$ & $204^{a}$ & 220 & 25 \\
\hline Faeces, mg/d & 190 & 207 & 204 & 167 & 165 & 179 & 188 & 22 \\
\hline Absorbed, mg/d & 51 & 40 & 35 & 29 & 27 & 25 & 34 & 14 \\
\hline Urine, $\mathrm{mg} / \mathrm{d}$ & 7 & 6 & 8 & 11 & 6 & 10 & 9 & 4 \\
\hline Retained, mg/d & 44 & 34 & 27 & 18 & 21 & 15 & 27 & 14 \\
\hline$\%$ of intake & 18 & 14 & 11 & 9 & 11 & 7 & 12 & 6 \\
\hline$\%$ of absorded & 86 & 83 & 76 & 59 & 71 & 62 & 73 & 10 \\
\hline $\mathrm{mg} / \mathrm{kg} \mathrm{W}^{0.75}$ & 2.7 & 1.66 & 1.25 & 0.81 & 1.11 & 0.72 & 1.27 & 0.71 \\
\hline
\end{tabular}




\begin{tabular}{|c|c|c|c|c|c|c|c|c|}
\hline & \multicolumn{3}{|c|}{ Protein supplements } & \multicolumn{3}{|c|}{ Sugar supplements } & \multicolumn{2}{|c|}{ Overall } \\
\hline & WPC & CAS & DSM & HYLA & SUC & DW & mean & s.d. \\
\hline \multicolumn{9}{|l|}{ Copper } \\
\hline Intake, $\mathrm{mg} / \mathrm{d}$ & $30.8^{c}$ & $31.3^{\mathrm{b}}$ & $31.7^{\mathrm{a}}$ & $27.9^{\mathrm{ac}}$ & $24.4^{\mathrm{bc}}$ & $28.9^{\mathrm{a}}$ & 29.2 & 2.7 \\
\hline Faeces, mg/d & 19.7 & 21.8 & 20.8 & 19.7 & 17.5 & 19.7 & 19.9 & 1.7 \\
\hline Absorbed, mg/d & 11.1 & 9.5 & 10.8 & 8.3 & 6.9 & 9.3 & 9.3 & 1.8 \\
\hline Urine, $\mathrm{mg} / \mathrm{d}$ & 3.3 & 4.0 & 4.5 & $2.0^{a c}$ & $0.6^{\mathrm{bc}}$ & $3.3^{\mathrm{a}}$ & 3.5 & 2.4 \\
\hline Retained, mg/d & 7.8 & 5.5 & 6.3 & 6.2 & 6.4 & 6.0 & 6.4 & 2.1 \\
\hline$\%$ of intake & 25 & 18 & 20 & 22 & 26 & 21 & 22 & 7 \\
\hline$\%$ of absorded & 70 & 61 & 59 & 75 & 93 & 64 & 70 & 23 \\
\hline $\mathrm{mg} / \mathrm{kg} \mathrm{W}^{0.75}$ & 0.39 & 0.26 & 0.32 & 0.30 & 0.31 & 0.31 & 0.32 & 0.13 \\
\hline \multicolumn{9}{|l|}{ Zinc } \\
\hline Intake, $\mathrm{mg} / \mathrm{d}$ & $202^{\mathrm{b}}$ & $215^{a}$ & $211^{\mathrm{a}}$ & $154^{b}$ & $154^{b}$ & $159^{a}$ & 182 & 31 \\
\hline Faeces, mg/d & 129 & 139 & 120 & 95 & 89 & 111 & 114 & 23 \\
\hline Absorbed, mg/d & 73 & 76 & 91 & 59 & 65 & 47 & 69 & 23 \\
\hline Urine, $\mathrm{mg} / \mathrm{d}$ & 3 & 3 & 3 & 6 & 3 & 4 & 4 & 1 \\
\hline Retained, mg/d & 70 & 73 & 88 & 54 & 62 & 43 & 65 & 24 \\
\hline$\%$ of intake & 35 & 34 & 41 & 35 & 40 & 27 & 35 & 9 \\
\hline$\%$ of absorded & 96 & 96 & 97 & 91 & 94 & 91 & 94 & 3 \\
\hline $\mathrm{mg} / \mathrm{kg} \mathrm{W}^{0.75}$ & 3.39 & 3.60 & 4.24 & 2.50 & 2.87 & 2.01 & 3.10 & 0.98 \\
\hline \multicolumn{9}{|l|}{ Manganese } \\
\hline Intake, $\mathrm{mg} / \mathrm{d}$ & $59.2^{\mathrm{b}}$ & $61.9^{a}$ & $58.2^{\mathrm{b}}$ & $42.4^{b}$ & $42.3^{b}$ & $46.0^{\mathrm{a}}$ & 51.7 & 9.1 \\
\hline Faeces, mg/d & 53.7 & 56.8 & 54.9 & 39.4 & 36.6 & 44.1 & 47.9 & 8.2 \\
\hline Absorbed, mg/d & 5.5 & 5.1 & 3.4 & 3.0 & 5.7 & 1.9 & 4.0 & 2.9 \\
\hline Urine, $\mathrm{mg} / \mathrm{d}$ & 0 & 0 & 0 & 0 & 0 & 0 & 0 & 0 \\
\hline Retained, mg/d & 5.5 & 5.1 & 3.4 & 3.0 & 5.7 & 1.9 & 4.0 & 2.9 \\
\hline$\%$ of intake & 9 & 12 & 6 & 7 & 13 & 4 & 8 & 4 \\
\hline$\%$ of absorded & 100 & 100 & 100 & 100 & 100 & 100 & 100 & 0 \\
\hline $\mathrm{mg} / \mathrm{kg} \mathrm{W}^{0.75}$ & 0.27 & 0.35 & 0.16 & 0.13 & 0.26 & 0.09 & 0.20 & 0.11 \\
\hline
\end{tabular}

Means with different letters were significantly different: a,b,c $(\mathrm{P}<0.05)$; e,f,g $(\mathrm{p}<0.01)$.

Forsum, E. 1974. Nutritional evaluation of whey protein concentrates and their fractions. J. Dairy Sci. 57: $665-$

- 1975 a. Whey proteins for food and feed supplement. Protein nutritional quality of foods and feeds. (Ed. M. Friedman). Part 2: 433-470.

- 1975 b. Effect of dietary lactose on nitrogen utilization of a whey protein concentrate and its corresponding amino acid mixture. Nutr. Rep. Internatl. 11 (5): $419-428$.

Fox, P.F. 1982. Developments in dairy chemistry. 1. Proteins. Appl. Sci. Publ. London.

Hanrahan, T.J. 1971. Whey solids in the diet of growing-finishing pigs. 1. Dried whey as a feed for pigs. Ir. J. Agric. Res. 10: 1-7.

HarJu, M. 1984. Mojligheter att förbättra vasslens anvăndbarhet som fodermedel. Fodrets koncentrationsgrad till svin ur foder- och avelssynpunkt. NJF Seminarium $\mathrm{Nr}$ 57: 3: 1-8.

Henschel, M.J., Newport, M.J. \& Williams, J.A. 1983. Protein metabolism and digestion in neonatal pigs given diets with different proportions of casein and whey in the milk proteins. IV th. Int. Symp. Pro- tein metab. and nutr. Clermont-Ferrand. INRA Publ. II: $415-418$.

Jørgensen, H.H. \& FernandeZ, J.A. 1984. The influence of level of minerals and dietary fat on apparent absorption of minerals at the terminal ileum and overall in growing pigs. 35th. Ann. Meet. EAAP. 4 p.

Just, A., Jergensen, H., Fernandez, J.A. \& BechANDERSEN, S. 1983. Forskellige foderstoffers kemiske sammensaetning, fordøjlighed, energi- og proteinvaerdi til svin. 556 Beretn. Nat. Inst. Anim. Sci. Denmark. 99 p.

NĀsı, M., IKonen, M. \& AntILA, M. 1982. Carboxy methyl cellulose (CMC) whey product as protein source for growing pigs. J. Scient. Agric. Soc. Finl. 54: $395-401$.

- \& TanhuanpãA, E. 1981. The effects of sugar alcohols on metabolism of growing pigs. Acta vet. scand. 22: 344-354.

Rerat, A.A., Vaissade, V. \&. Vaugelade, P. 1984. Absorption kinetics of some carbohydrates in conscious pigs. 1. Quantitative aspects. Br. J. Nutr. 51: 505-515.

SCHingoethe, D.J. 1976. Whey utilization in animal 
feeding: A summary and evaluation. J. Dairy Sci. 59: 556-570.

SснміDт, M. 1979. Laboratory testing in veterinary medicine. Diagnosis and clinical monitoring. Boehring mannheim GmbH. 130 p.

SAlo, M-L., TUORı, M. \& KiISkinen, T. 1982. Rehutaulukot ja ruokintanormit. Helsinki. 70 p.

TAYSSKY, H.H. \& SHORR, E. 1953. A microcolorimetric method for the determination of inorganic phosphorus. J. Biol. Chem. 202: 675-685.

\section{SELOSTUS}

\section{Eri heravalmisteiden rehuarvosta ja fysiologisista vaikutuksista lihasialla}

\section{Matti Näsi}

Helsingin yliopisto, Kotielaintieteen laitos, 00710 Helsinki

Sulavuus- ja tasekokeissa tutkittiin ultrasuodatetun heravalkuaisrikasteen arvoa lihasian valkuaislähteenä vertaamalla sitä kaseiiniin ja rasvattomaan maitojauheeseen ohrapohjaisella ruokinnalla. Samoin verrattiin entsymaattisesti hydrolysoitua laktoosisiirappia sakkaroosiin ja kuivattuun herajauheeseen (laktoosiin), kun niillä korvattiin $30 \%$ ohrasta. Tutkimuksessa selvitettiin nåiden lisăysten vaikutusta lihasian valkuais- ja kivennäisaineenvaihduntaan. Heravalkuaisrikasteen proteiinipitoisuus oli $\mathbf{4 2 , 2} \%$ ja siină oli runsaasti lysiiniă ja rikkipitoisia aminohappoja. Laktoosisiirapin hydrolyysiaste oli $73 \%$. Heravalkuaisrikasteen proteiinin sulavuus oli korkea, $99,1 \%$, kun taas herajauheen proteii-
Thorbek, G. \& Ludvigsen, J.B. 1961. The effect on the nitrogen metabolism in artificially reared piglets by feeding different sources of carbohydrates. Festschrift zum VIII Internat. Tierzuchtkongress in Hamburg.

Womack, M. \& Vaughan, D.A. 1972. Whey and whey products as cereal supplements. J. Dairy Sci. 55: 1081-1084.

Ms received September 20, 1984 nin sulavuus jäi alhaiseksi, 72,5\%. Valkuaisen hyvăksikăyttő oli heravalkuaista sisăltävällä dieetillä muita korkeampi mitattuna typpitaseella ja urean erityksenä virtsassa. Valkuaisen hyväksikäyttö oli niinikäăn heravalkuaisrikastetta ja hydrolysoitua laktoosisiirappia sisältăvăllă dieetillă tehokkaampaa kuin herajauhetta sisăltăvăllă dieetillä. Veriparametrien perusteella arvioituna suuret laktoosi- ja/tai kivennăismăărăt eivăt olleet sioille haitallisia. Siat joivat vettă keskimäărin $49 \%$ enemmăn sokereita sisăltăvillă dieeteillä. Natriumin ja kaliumin ylimăărăt erittyivăt virtsassa, eikă sioilla esiintynyt ripulia suurien sokeri- ja/tai kivennäismäärien takia. 